\title{
Community Contribution Companies and Access to Social Finance
}

\author{
Bridget $\mathrm{M} \mathrm{Horel}^{1} \&$ Kevin McKague ${ }^{1}$ \\ ${ }^{1}$ Shannon School of Business, Cape Breton University, Canada \\ Correspondence: Kevin McKague, Shannon School of Business, Cape Breton University, 1250 Grand Lake \\ Road Sydney, Nova Scotia, Canada B1P 6L2. E-mail: Kevin_McKague@cbu.ca
}

Received: June 5, 2018

doi:10.5539/jsd.v11n5p126
Accepted: August 14, $2018 \quad$ Online Published: September 28, 2018

URL: https://doi.org/10.5539/jsd.v11n5p126

\begin{abstract}
There is widespread agreement that innovative funding solutions are necessary to address capital requirements of social enterprises, social purpose businesses and not-for-profits in the social economy. The community contribution company (C3) is a legal organizational form for social enterprise, introduced in British Columbia, Canada, in 2013. In creating this legal form, the British Columbia government intended to provide social entrepreneurs with a recognized legal structure designed, in part, to assist social enterprises in gaining access to investment capital. Drawing on interviews from 14 of the 35 registered C3s and a review of filing data, this study provides information to help understand what attracted organizational founders to the $\mathrm{C} 3$ model, what challenges are experienced by $\mathrm{C} 3 \mathrm{~s}$ engaging with investors and financial institutions, and what opportunities there are for improvement to the $\mathrm{C} 3$ legal form. This study found that reasons outside a motivation to access investment capital are key driving factors for incorporating as a C3; there is currently a low level of engagement from impact investors; financial incentives may have a role in increasing investment in C3s; and there is an expressed need and opportunity to enhance education about the model to further support C3s. While the consensus from interview respondents was that benefits of incorporating as a $\mathrm{C} 3$ outweighed disadvantages, we found that the model has not helped organizations attract social finance and investment. As this model is in relatively early stages of implementation, the lessons learned in this study can inform investors, social finance intermediaries, entrepreneurs, and policy makers.
\end{abstract}

Keywords: British Columbia, Canada, community contribution company, C3, social enterprise, social finance

\section{Introduction}

An increased demand for, awareness of, and support for social finance has changed the way that social enterprises secure capital. Social finance is "the deliberate, intentional application of tools, instruments, and strategies to enable capital to achieve a social, environmental, and financial return" (Harji \& Hebb, 2010). Increased interest in social finance has emerged from a decline in government funding, increased demand for social services, and increases in socially responsible investment (Bugg-Levine \& Goldstein, 2009, Hebb, 2012). In Canada, social finance has been used to varying degrees in a number of sectors such as affordable housing, agriculture, energy, and health (Harji \& Reynolds, 2014).

\subsection{The Need for Innovation in Social Finance}

There is widespread agreement that innovative funding solutions are necessary to address capital requirements of social enterprises, social purpose businesses and not-for-profits in the social economy (Bugg-Levine \& Goldstein, 2009; Harji \& Jackson, 2012; Hebb, 2012; Myers, Conte, \& Nichols, 2013; Phillips \& Hebb, 2010). In Canada, the development of new corporate legal forms has been precipitated by the rise of social enterprise and the increasing demand to access capital while ensuring the integrity of an organization's social purpose (Liao, 2013; Reiser, 2010). Concurrently, structures enabling social finance are meant to help impact investors wanting to invest in projects that provide blended social and financial returns.

This study provides information on the demand side of social finance by examining community contribution companies (C3s), a new legal form for social enterprise introduced in British Columbia (B.C.), Canada, in 2013. The purpose of this study was to provide researchers, practitioners and communities with information to help understand what attracted organizational founders to the $\mathrm{C} 3$ model, what challenges $\mathrm{C} 3 \mathrm{~s}$ are experiencing when engaging with investors and financial institutions, and what opportunities there are for improvement in the $\mathrm{C} 3$ legal form. 
A review of organizational filing documents for all 35 C3s registered in B.C., as well as interviews with organizational leaders from 14 C3s held between February and March 2016, revealed that C3s are receiving a low level of finance in general and are not receiving financing from impact investors or social finance organizations. Data showed that there are several reasons for this including lack of awareness of the model from funding and financing bodies, the early stage of development of many of the $\mathrm{C} 3 \mathrm{~s}$, and the challenge of aligning investors' motivations with the C3's purpose and mission. Data revealed that the greatest challenge C3 founders currently faced was the lack of awareness and understanding of the model among many stakeholders, the limited support available from government, and the absence of a tax incentive for potential investors.

\subsection{Literature Review: The Social Finance Ecosystem}

Within the social finance marketplace there are supply, demand, and intermediary roles. Actors who require social finance (demand side) are often linked with actors who provide social finance (supply side) through organizations that play a transactional (intermediary) role (Myers et al, 2013). Social finance is distinct from other financing forms as it is specifically designed to address the financing gap facing social enterprises and other organizations within the social economy (Geobey, Westley, \& Weber 2012; Karaphillis, Asimakos, \& Moore, 2010). Social finance, meaning "the deliberate and intentional application of tools, instruments, and strategies to enable capital to achieve a social, environmental, and financial ('blended value') return" (Harji \& Hebb, 2010) and impact investing, meaning "investments made into companies, organizations, and funds with the intention to generate measurable social and environmental impact alongside a financial return" (Hangl, 2014), are sometimes used interchangeably, as we do for the purposes of this study. At other times, impact investing is identified as a component within the social finance approach. A key factor differentiating impact investment from social finance is the intentionality around measuring social impact (Harji \& Reynolds, 2014).

Figure 1 identifies social finance along a spectrum of finance types. These various social finance types are indicative of investors' increased awareness of sustainability issues and concern for the environmental, social, and governance (ESG) standards of a company (Hebb, Hachigian, and Allen, 2011). As one moves further right along the spectrum, there is an increased emphasis on investing in companies that offer blended social, environmental, and financial returns.

\begin{tabular}{|c|c|c|c|c|c|}
\hline & & \multicolumn{4}{|c|}{ Impact investment } \\
\hline Traditional & $\begin{array}{c}\text { Responsible } \\
\text { Investing (RI) }\end{array}$ & $\begin{array}{c}\text { Socially } \\
\text { Responsible } \\
\text { Investing (SRI) }\end{array}$ & Finance-First & Impact-First & $\begin{array}{c}\text { Venture } \\
\text { Philanthropy }\end{array}$ \\
\hline $\begin{array}{l}\text { Limited or no } \\
\text { analysis of ESG } \\
\text { standards }\end{array}$ & $\begin{array}{l}\text { ESG analyzed } \\
\text { and risks } \\
\text { integrated as a } \\
\text { component of } \\
\text { investment } \\
\text { decision and } \\
\text { risk } \\
\text { management }\end{array}$ & $\begin{array}{lr}\text { ESG risks } \\
\text { (positive and } \\
\text { negative) are } \\
\text { screened } \\
\text { align portfolio } \\
\text { to } \\
\text { values }\end{array}$ & $\begin{array}{l}\text { Focus on one or } \\
\text { more social or } \\
\text { environmental } \\
\text { areas where no } \\
\text { financial } \\
\text { trade-off is } \\
\text { required }\end{array}$ & $\begin{array}{l}\text { Focus on one or } \\
\text { more social or } \\
\text { environmental } \\
\text { areas where a } \\
\text { financial } \\
\text { trade-off may be } \\
\text { required }\end{array}$ & $\begin{array}{l}\text { Funding for } \\
\text { social enterprise } \\
\text { with a variety of } \\
\text { return } \\
\text { possibilities }\end{array}$ \\
\hline \multicolumn{6}{|c|}{ Provide Competitive Financial Returns on Investment } \\
\hline & \multicolumn{5}{|c|}{ ESG Factors Included in Risk Analysis and Management } \\
\hline & & High Impact Solv & ions & & \\
\hline
\end{tabular}

Figure 1. Spectrum of investment types

Literature shows an increasing interest from investors, foundations, and financial institutions in financing projects that can provide a positive social and/or environmental impact as well as a financial return on investment (Bugg-Levine \& Goldstein, 2009). For this reason, the hybrid model of a "corporate entity that embodies legal tools which require and/or encourage the pursuit of dual economic and social mandates within businesses" (Liao, 2014) has become an instrument in these endeavours and in the creation of the community contribution company form in particular. 


\subsection{The C3 Model}

A community contribution company (C3) is a hybrid corporate model for social enterprise that "bridges the gap between a for-profit business and not-for-profit enterprise" (Canada Business Network, 2015). The C3 model was developed in response to some of the limitations facing social enterprises such as access to capital, the pursuit of dual or multiple purposes, and development of distinguishable branding (Lee, 2015). In order to raise equity capital, C3s can issue shares - opening up an opportunity previously not available to not-for-profit and charitable organizations in B.C. (Lee, 2015; Liao, 2013).

The $\mathrm{C} 3$ model is based on the community interest company (CIC) - an organizational form implemented in the United Kingdom in 2005 (Liao, 2013). C3s were introduced in B.C. to provide social enterprises with a recognized legal form "in response to an emerging demand for socially focused investment options" (British Columbia Ministry of Finance, 2016a). B.C. was the first province in Canada to have adopted this model. In June 2016, Nova Scotia became the second province in Canada to pass legislation and regulations allowing a business to become designated as a CIC (Service Nova Scotia, 2016). Both British Columbia and Nova Scotia took their inspiration from the UK model.

Unique attributes that define the $\mathrm{C} 3$ from other incorporation structures in B.C. are the community purpose asset lock provision, dividend cap, and the obligation that directors consider outside stakeholder and community interests. In order to ensure that assets are not sold for below fair market value, an asset lock feature exists to place a limit on the assets that a shareholder can receive when a $\mathrm{C} 3$ is dissolved (British Columbia Ministry of Finance, 2016b). A minimum of $60 \%$ of the assets must be transferred to another $\mathrm{C} 3$, not-for-profit organization, or qualified entity to further the community purposes (Liao, 2013). To provide assurance that the C3 is committed to its community purpose, there is a cap on the amount of dividends that can be paid to shareholders (Liao, 2013). The dividend cap is set to $40 \%$ of the C3's annual profit (leaving $60 \%$ to go toward the community purpose), but the cap does not apply to dividends paid to qualified entities (BC Centre for Social Enterprise 2015). Qualified entities can include community service corporations, registered charities and other asset-locked entities, as well as First Nations and Aboriginal groups (British Columbia Ministry of Finance 2016b). One or more of a C3's primary purposes must be community benefit (Business Corporations Act, 2015). Directors of $\mathrm{C} 3 \mathrm{~s}$ are required to report how the company has both engaged stakeholders and benefited the community (Liao, 2013). C3s are understood to be held to a "higher degree of accountability" (British Columbia Ministry of Finance, 2016b) and require at least three directors, as opposed to one director in B.C. company corporations. They must also publish a Community Contribution Report.

In several ways, C3s are treated like for-profit B.C. companies - they will not receive any federal tax exemptions, will not be able to issue tax receipts, and they must comply with securities regulations around registration and disclosure (British Columbia Ministry of Finance, 2016b). Unless they engage in sale of shares through an exempt form (i.e., memorandum, accredited investor, minimum investment, or family, friends, and business associates exemptions), C3s must also issue a prospectus (British Columbia Ministry of Finance, 2016b). Although the $\mathrm{C} 3$ organizational form introduced in B.C. was the first in Canada, no research to date has examined its effectiveness in practice. In this paper we address this gap by gathering data on whether or not the C3 structure has been successful in assisting social entrepreneurs to access social finance. Our research also explored what can be learned from the experiences of the organizational founders who have incorporated under the model in B.C.

\section{Methodology}

\subsection{Compiling the Sample}

In order to assess the effectiveness of the $\mathrm{C} 3$ organizational form in helping attract social finance and the perceptions of what worked well and what could be improved upon, qualitative data was gathered from interviews with organizational leaders and from organizational filings with the province of B.C. As required by the B.C. Business Corporations Act, all C3 companies must include the words "community contribution company" or the acronym "CCC" in their name when they register their organization (Business Corporations Act, 2015). The B.C. business names registry was thus searched for the terms "CCC" as well as "community contribution company" in order to capture those companies that were incorporated as C3s. The initial search for CCC revealed 37 company names and an additional 12 company names were found using "community contribution company," establishing a preliminary list of 49 potential C3s. However, of these, nine had "B.C. company" listed as the incorporation type and one had "society" listed as the incorporation type. These ten were removed from the list of potential research participants, as they were not companies incorporated under the $\mathrm{C} 3$ structure. Two were listed as "extraprovincial registration." The B.C. registry office was contacted to determine 
whether these companies were $\mathrm{C} 3 \mathrm{~s}$ and the response indicated that these two companies were unlikely to be C3s, and they were removed from the sample population. Another two, listed as "Reserved," were removed from the sample population as there were no corporate summaries available for them and no additional information was available online to confirm whether or not they were C3s. With the changes indicated above, the list of C3s was reduced to $35 \mathrm{C} 3 \mathrm{~s}$ (see Appendix A for the list of $\mathrm{C} 3 \mathrm{~s}$ ).

\subsection{Contact and Interview}

A corporate summary request was sent to the B.C. Registry which returned the following information on the 35 C3s: status, recognition date (when the company was incorporated or registered, amalgamated, continued out or into the province), incorporation number, last annual report filing date, previous company name(s) if applicable, registered office address, records office address, names of directors, and names of officers (if provided). Subsequent online searches identified contact information for 33 of the C3s. These C3s were contacted by phone and email requesting one semi-structured interview with the possibility of a follow-up email or second short interview if required. Fourteen $\mathrm{C} 3 \mathrm{~s}$ agreed to participate in the study for a response rate of $40 \%$. Interviews were conducted by telephone and lasted between 20 and 45 minutes. A series of interview questions were developed in advance and shared with an industry expert for feedback. Interview respondents were organizational directors, management or founders. All interviews were audio recorded and written notes were taken. After each interview, the audio recording was reviewed and transcribed.

\subsection{Data Analysis}

As interviews were reviewed and transcribed, researcher memos were written to begin the process of categorizing and identifying relationships within the data (Maxwell, 2013). The interview transcriptions were loaded into a qualitative data analysis and research software program (Atlas.ti) and coded to identity themes and to compare and contrast the experiences of different respondents. This coding helped to calculate the most frequently cited motivations for incorporating as a $\mathrm{C} 3$, perceptions of access to financing, and hindering and/or enabling factors of the $\mathrm{C} 3$ model.

Data analysis was conducted in conjunction with data collection. Throughout the data collection and analysis process, researcher memos were expanded to stimulate analytical thinking, ensure reflection on the process, and help gauge validity threats (Creswell, 2014). The use of structured and open-ended questions was intended to increase the validity and inference quality of the research. Researcher bias was reduced during the interview process by including both style of questions and by conducting verbatim transcription. Interviewees were provided with a summary of the results in order to build in another level of accountability and further reduce threats to data validity and quality.

\section{Results}

To provide an overview of the C3s that exist in B.C., data gathered and analysed from the corporate summary documents are presented first. Following this, data is presented from interview respondents on motivations for selecting the model, the relationship between $\mathrm{C} 3 \mathrm{~s}$ and social finance, and respondent perceptions of what has worked well to date and what could be improved.

\subsection{Geography, Incorporation History, and Size of C3s in Operation}

Analysis of C3 registration data found that the majority of C3s were registered in Vancouver (20), with 15 registered in other cities across the province. In the year 2013, when the option became available, $10 \mathrm{C} 3 \mathrm{~s}$ registered in B.C., 12 followed in 2014, and 13 registered in 2015. While most of the C3s had registered under the $\mathrm{C} 3$ model initially, eight were previously incorporated as B.C. corporations and then converted to the $\mathrm{C} 3$ structure. Three of the companies were not in good standing with the provincial government and, of these, two were in the process of being dissolved. Almost all of the C3s interviewed were in the start-up phase and had fewer than five full-time employees. Some of the C3s had unpaid volunteers who worked ten or more hours per month and some were run entirely by unpaid volunteers.

\subsection{Founder Motivation}

Data from interviews identified a variety of reasons for choosing to incorporate under the $\mathrm{C} 3$ legal form. Many respondents expressed an appetite for a structure that was better able to reflect their values and convictions. Some of those interviewed had selected the model to be an enterprising entity for an associated parent organization (not-for-profit or charity). Other factors motivating the choice to incorporate under the $\mathrm{C} 3$ structure included accountability back to the community, revenue diversification to increase financial self-sustainability, and advocacy and marketplace building for social purpose and blended value businesses. Some interviewees described desiring a structure that would legally ensure the commitment to community contribution into the 
future.

Those interviewed had largely learned about the C3 model through their own research into different organizational structures, with some citing research into European and American models. As one respondent noted:

"When I was doing research, trying to figure out the best structure, I was looking at charities, non-profit societies, looking at the British and US models for C3, and trying to figure out the best way that we could build mission-driven governance into the legal structure of the organization."

Others had learned about $\mathrm{C} 3 \mathrm{~s}$ through their work and volunteer experience in the social economy sector, in discussions with others about different organizational forms, or from being a part of the stakeholder group that worked with government to design the legislation and regulations. The majority of respondents had directors or founders who were extremely familiar with the concept of social enterprises before adopting the $\mathrm{C} 3$ model.

\subsection{Reasons for Selecting the C3 Structure}

As shown in Table 1, marketing and branding and the asset lock and/or dividend cap features were the two most frequently cited factors for selecting the $\mathrm{C} 3$ structure, followed by governance and control, other reasons, financing and investment, and corporate accountability.

Table 1. Ranking of motivations to incorporate as a community contribution company

\begin{tabular}{lc}
\hline Motivations for C\# Incorporation & \# of Times Ranked in Top 2 \\
\hline Marketing / Branding & 7 \\
Asset Lock / Dividend Cape Features & 7 \\
Governance / Control & 4 \\
Financing / Investment & 2 \\
Corporate accountability & 2 \\
Other & 4 \\
\hline
\end{tabular}

While marketing or branding was selected as one of the top two reasons by half of the respondents, it was described in various ways using different terminology (e.g., optics, positioning, messaging). A few interviewees noted that part of the reason for picking the $\mathrm{C} 3$ model was because the structure itself publicly demonstrates their strong commitment to giving back to the community. As one respondent noted:

"Our decision was almost like a statement and a commitment to say that we want to lock in legally that this is a venture that is [meant] to lead to social impact so when people are sitting around the table years down the road that is legally locked."

Governance or control was also acknowledged as a factor, especially when compared to not-for-profit and charitable organizational structures. As one respondent noted:

"We had an entrenched social purpose but we felt that social entrepreneurship was a more powerful model than going to a non-profit structure. So the intention was never to make any money but we wanted the flexibility to run like a private business and a for-profit business so we could have the maximum impact and we wanted to avoid all the bureaucracy of charities and non-profits but still achieve a similar social mission."

Another respondent stated that there was more decision-making power with a $\mathrm{C} 3$ than with a not-for-profit; the respondent felt that there were more rights and privileges to be had as a result of having ownership over the company. Another interviewee explained that the C3 structure gave owners more control, which allowed more continuity of program development and implementation. Flexibility was a factor that interviewees noted as a positive feature when commenting on aspects of governance and control.

"A flexible charitable structure, which is what we basically created by self-mandating a C3, that's number one...We liked the fact that we had a different model of governance possible and that we could control it more than we could if we turned it into a non-profit society. We 
could control it because of the governance and we could control it because it doesn't have the same government rules."

Three of the interviewees identified that they had further adjusted the $\mathrm{C} 3$ structure to align with their motivations for selecting the model. The structure was adjusted differently by each of the three respondents. The first respondent altered the organization's articles of incorporation to self-mandate giving $100 \%$ of the profits back to the community. The second wrote the organization's mission to enhance the $\mathrm{C} 3 \mathrm{~s}$ accountability to the community and to acknowledge the social capital built within the community. The third established a sustainability charter to ensure the priorities for health and well-being were maintained. A third of interview respondents agreed that attracting investment was part of their motivation for registering as a C3. Of these, only two interviewees ranked finance and investment as one of their top two reasons for selecting the model.

\subsection{C3s, Financing, and Impact Investment}

None of the C3s interviewed had accessed impact investment and none of the interviewees had received an investment that had any expectation of financial returns alongside social returns. Several factors contributed to the low number (four) of interviewees who reported having received financing since being registered as a C3. Many were new and still in the start-up phase. Some interviewees were just starting the process of engaging with potential investors. Others had not been pursuing investment either because they had adequate funds (founder and/or parent organization) or because their business model was not designed to attract investment. For those seeking financing, a lack of awareness and understanding of the model from funding and financing bodies was identified as a challenge. In addition, investor's motivations did not align with the C3s purpose and mission. Several interviewees indicated that funders and investors, including financial institutions, government, and foundations, did not understand what the $\mathrm{C} 3$ model is and did not know how to categorize these companies. Another commonly identified issue, recognized as a barrier to accessing financing, was the inability of C3s to offer a tax receipt to those interested in donating or investing. One respondent, comparing the $\mathrm{C} 3$ to a standard B.C. company structure, noted that the model's asset lock and dividend cap features and the restrictions around merging with other companies may discourage potential investors.

"You can go public as a CCC, which is great, but you can't get acquired by a for-profit and if you [investors] are looking at start-ups you are looking at exit strategies and investors will say what are your exit strategies and we can say well we can go public but we can't merge with a company...I would say you probably limit yourself quite a bit more. Although you do have access to some investors who only invest in social enterprises I think you probably lose a lot more than you gain."

Another felt that investors were likely to be more lenient or patient with $\mathrm{C} 3 \mathrm{~s}$ in relation to expectations around profitability of the enterprise and their return on investment.

\subsection{Types, Sources, and Amounts of Finance}

Most of the $\mathrm{C} 3 \mathrm{~s}$ were financed through parent organizations, founder capital, personal loans and funds, and own source revenue. Of those interviewed, only four reported having received outside financing as a registered $\mathrm{C} 3$. This financing came mainly in the form of donations, sponsorships, and loans under CDN \$10 000 from private businesses and local credit unions. One of the respondents, categorized by funders as a not-for-profit, qualified for granting programs, and one other respondent had a small grant under CDN $\$ 10000$. One respondent had received a loan from a local credit union in the CDN \$100 000 to CDN \$150 000 range, and one C3 director was waiting to hear from an undisclosed foundation about the possibility of receiving a CDN \$500 million grant for land purchase and capital costs.

\subsection{Founder Perceptions of What Was Working Well}

All of the respondents said "yes" when asked if they would have chosen the C3 structure if they were incorporating again. Several interviewees pointed out key aspects that supported their positive perception of the benefits of the $\mathrm{C} 3$ model.

"Yes I really like it. For me it is a kind of innovation that is very ideal because it depends on the concept of business but it is not all just about profit and at the same it pays back to the owner versus a non-profit."

The reporting structure and requirements were identified as a positive for some $\mathrm{C} 3 \mathrm{~s}$ who noted that the report enabled them to illustrate to groups, individuals, and community members the C3's contribution to the community. The model enabled some to gain organizational clarity. Flexibility within the structure to advocate, and the ability to give money away, hire people, and have volunteers were also noted as positive features. 


\subsection{Founder Perceptions of Challenges}

The most frequently reported challenges with the $\mathrm{C} 3$ form were not in relation to the structure itself but the lack of awareness and understanding of the model, the limited support available, and the absence of a tax incentive for potential investors. Some referred to the limited awareness and understanding as a challenge with the newness of the model while others referred to it as a result of a lack of government and sector support. As one respondent noted:

"The single largest issue is just that the organizations or entities that we interface with, particularly at the provincial government, have no idea where to put $\mathrm{C} 3 \mathrm{~s}$ on their forms and in their thinking...The province wants to treat us like a non-profit because we are community minded and so they had to create a whole lot of new paper."

For most respondents, a limited understanding of the model by organizations, government departments, funders, financial institutions, clients and customers was identified as a challenge.

Respondents noted that organizations, government bodies, and potential customers and clients were unsure how to categorize the $\mathrm{C} 3$. The impact that this lack of understanding had on financing was noted by several interviewees. One respondent explained that it was a struggle to set up a bank account because the corporate structure was not understood. Another respondent, finding the lack of infrastructure for C3s extremely challenging, formed a second incorporated business to facilitate the purchase of land and access a mortgage. The lack of knowledge and understanding about the $\mathrm{C} 3$ model also had implications for marketing and accessing professional support. More than one interviewee identified that it was difficult to find a lawyer who understood the model. A lack of consolidated information for organizational founders was also identified as a challenge. Some of the interviewees noted that they still had questions about aspects of the model, such as joint ventures, as well as what was required and expected of them.

Concern about the absence of tax incentives for investors and people who want to donate was conveyed by several interviewees. More than one interviewee noted that there is no tax incentive to the $\mathrm{C} 3$ model. Some interviewees noted that they had interest from people who would like to receive a tax receipt for donations. As stated by one respondent:

"We ended up opening up a non-profit and charitable arm of what we are doing but that was just more of a shift of our own model. We have a lot of people who want to contribute who want a tax receipt to do so. So it was a bit of a function of the market that sort of required that."

One respondent described that in order to acknowledge and access funds from those who wanted to donate, some restructuring had to be done to form a charitable arm for their organization.

Respondents were asked what suggestions they had for features that might attract social entrepreneurs, financiers, potential partners, and customers to the $\mathrm{C} 3$ model. Additional education and public information, tax incentives, support for entrepreneurs, and a network for the $\mathrm{C} 3$ marketplace were all identified as ways to improve upon the current situation. One respondent felt that if the owners of $\mathrm{C} 3 \mathrm{~s}$ had a way to get together, they might be able to broaden their impact:

"I think that there is no adequate community for other C3s though. I have had a really hard time interacting well with others because we are all at the experiment stage so nobody has the time to sort of sit down at a round table and hash things out it seems ....so the lack of sector support I guess. We are all going it alone because we are all trying to figure it out."

Another interviewee said that there should be more support for those trying to explain the model to clients and investors. Several interviewees suggested that it is necessary to increase awareness of and support for C3s.

\subsection{Advice for Others Considering C3}

The advice that respondents would give to others considering the $\mathrm{C} 3$ form can be summarized into four key messages: gain clarity of purpose and motivations; consider other, more established structures that may meet your needs; prepare for challenges; and consider that there is a shifting business context which may favour hybrid models in the future. Each is further described below.

\subsubsection{Clarity of Purpose}

The most frequently identified piece of advice from respondents was that those considering the $\mathrm{C} 3$ model must be clear about their own motivation, the motivations of the other stakeholders involved, and the business purpose before selecting the model. This included the recommendation that plans contain a clear business concept, 
potential sources of capital, and an understanding of the image that the business would like to present:

"You may have multiple stakeholders with multiple understandings of why you are coming together so I think you have to be crystal clear what the company is going to be about and make sure that everyone is on the same page."

One respondent felt that if an organization is strictly focused on financial gain, the $\mathrm{C} 3$ model is not a good choice because of the dividend and asset cap features, but if they are interested in operating a sustainable business that considers both current and future generations, then the $\mathrm{C} 3$ model can be a good choice.

\subsubsection{Consider Established Structures}

A second piece of advice offered was to examine whether or not there are other, more established, business structures that could fulfill the business purpose and meet the goals of the entrepreneur. One respondent recommended that the business incorporate as a standard B.C. company and then convert to a $\mathrm{C} 3$ when it seemed most suitable.

\subsubsection{Prepare for Challenges and Shifting Contexts}

One respondent felt that those considering the model should "just be prepared to fight," commenting that incorporating under the model might feel like breaking ground because of its newness. Other suggestions were that those working under the model might look to private corporations, as opposed to government, for financial support, and make communications material and information available when approaching clients, funders, and investors. A few of the interviewees expressed a view that businesses with a commitment to their social purpose would gain more ground in future, and noted that $\mathrm{C} 3 \mathrm{~s}$ have the potential to be a good model for business.

\section{Discussion and Conclusions}

The consensus from interview respondents was that the benefits of incorporating as a $\mathrm{C} 3$ outweighed the disadvantages. In Canada, the role and value of the social economy in addressing challenging social and environmental problems is becoming increasingly recognized. Despite the rise of social finance and hybrid organizations, much of the infrastructure, systems, mindsets, and markets still impose binaries of charity or business, philanthropy or profit maximization, financial performance or community contribution, and as a result, C3s exist in a challenging space.

While not accurate for all existing C3s, the responses from founders, directors, and/ or management staff representing 14 out of $35 \mathrm{C} 3 \mathrm{~s}$ reveals common themes and experiences that can allow for generalizations to be made around impact investment and the C3 landscape in B.C. Drawing from a review of filing data and interview results, this study of $\mathrm{C} 3 \mathrm{~s}$ finds the following main conclusions: reasons outside a motivation to access investment capital are the key driving factors to incorporation as a $\mathrm{C} 3$; there is currently a low level of engagement from impact investors; financial incentives may have a role in increasing investment in $\mathrm{C} 3 \mathrm{~s}$; and there is an expressed need and opportunity to enhance education about the model and to further support C3s.

Rather than the ability to attract equity capital through investment, those incorporating under the $\mathrm{C} 3$ structure appear to be motivated by the commitment to social purposes integral to the $\mathrm{C} 3$ structure, the alignment with blended values, the flexibility of the model - both in terms of revenue diversification and governance, and the marketing and branding opportunities. In general, access to new sources of capital and investment is a factor influencing entrepreneur selection of the $\mathrm{C} 3$ model but is not a key motivating factor. Alternately, it is possible that those pursuing increased access to investment capital are not selecting the $\mathrm{C} 3$ model.

The most common types, sources, and amounts of financing being received by $\mathrm{C} 3 \mathrm{~s}$ do not indicate a high level of engagement from impact investors. Currently, none of the $\mathrm{C} 3 \mathrm{~s}$ interviewed have accessed impact investment as defined in this study, as none of the interviewees had received an investment that had any expectation of financial returns alongside social returns. This study demonstrates that there are several reasons why C3s have not attracted investment capital. Some C3s have not attempted to attract investors and others are not designed with intent to attract investors. The newness of the model, and a limited understanding and awareness of C3s have acted as barriers in accessing finance for some. Difficulty with alignment of investor and founder values has been a challenge for at least one $\mathrm{C} 3$.

In contradiction to one of the espoused objectives of the $\mathrm{C} 3$ structure, we found that it has not helped organizations attract social finance and investment. Respondents indicated that the inability of the $\mathrm{C} 3$ model to offer financial advantages to promote investment (i.e. no tax benefits and capped dividends) was a disincentive to attracting finance. As a result, it may be beneficial for B.C. to implement some form of tax relief for those who invest in $\mathrm{C} 3 \mathrm{~s}$, as the UK has done with the CIC and as Nova Scotia has done with the Community 
Economic Development Investment Funds (Pawson, 2013).

The development of mechanisms to assist both the supply and demand sides of impact investment is an important objective, and $\mathrm{C} 3 \mathrm{~s}$ are one such demand side mechanism. While this model is still new to B.C., there are important lessons that can be learned, even at this relatively early stage of implementation, to inform investors, social finance intermediaries, entrepreneurs, and policy makers.

\section{Acknowledgements}

The authors gratefully acknowledge funding support from the Social Sciences and Humanities Research Council of Canada and the assistance of Douglas Pawson and Dr. Jodi McDavid.

\section{References}

BC Centre for Social Enterprise. (2013, June). Legal structures for social enterprise in BC. Presentation given in Vancouver and Victoria. Retrieved from http://www.centreforsocialenterprise.com/wp-content/uploads/2015/08/Structure_Shop_PPT.pdf

British Columbia Ministry of Finance. (2016a). Community contribution companies. Retrieved from http://www.fin.gov.bc.ca/prs/ccc/index.htm

British Columbia Ministry of Finance. (2016b). Questions and answers: Community contribution companies (C3s). Retrieved from http://www.fin.gov.bc.ca/prs/ccc/caq.htm.

Bugg-Levine, A., \& Goldstein, J. (2009). Impact investing: Harnessing capital markets to solve problems at scale. Community Development Investment Review, 5, 30-41.

Business Corporations Act. (2015). Part 2.2 - Community contribution companies. BC laws. Retrieved from http://www.bclaws.ca/civix/document/id/complete/statreg/02057_03a

Canada Business Network. (2015). Community contribution company. Retrieved from http://entreprisescanada.ca/eng/program/4574/

Creswell, J. W. (2014). Research design: Qualitative, quantitative, and mixed methods approaches (4th ed.). Thousand Oaks, CA: SAGE Publications.

Geobey, S., Westley, F. R., \& Weber, O. (2012). Enabling social innovation through developmental social finance. Journal of Social Entrepreneurship 3(2), 151-165. https://doi.org/10.1080/19420676.2012.726006

Hangl, C. (2014). A literature review about the landscape of social finance. ACRN Journal of Finance and Risk Perspectives, 3(4), 64-98.

Harji, K., \& Hebb, T. (2010, May). Investing for impact: Issues and opportunities for social finance in Canada. Paper presented at ANSER Conference, Montreal. Retrieved from http://www.anser-ares.ca/files/conf10/papers/Harji\%20\&\%20Hebb\%20ANSER2010.pdf

Harji, K., \& Jackson, E. T. (2012). Accelerating impact: Achievements, challenges, and what's next in building the impact investment industry. New York: Rockefeller Foundation. Retrieved from https://assets.rockefellerfoundation.org/app/uploads/20120707215852/Accelerating-Impact-Full-Summary.p $\mathrm{df}$

Harji, K., \& Reynolds, J. (2014). State of the nation: Impact investing in Canada. Toronto, ON: MaRS Centre for Impact Investing and Purpose Capital. Retrieved from https://www.marsdd.com/wp-content/uploads/2014/09/Impact-Investing-in-Canada-State-of-the-Nation-201 4-EN.pdf

Hebb, T. (2012). The utilization of social finance instruments by the not-for-profit sector. Working Paper \#12-02. Ottawa, ON: Carelton Centre for Community Innovation. Retrieved from https://carleton.ca/3ci/wp-content/uploads/3ci-Utilizing-Social-Finance-Report-August-16-Final1.pdf

Hebb, T., Hachigian, H., \& Allen, R. (2011). Measuring the impact of engagement in Canada. In T. Hebb (Ed.), The next generation of responsible investing (pp. 107-125). Dodrecht, Netherlands: Springer. https://doi.org/10.1007/978-94-007-2348-1_7

Karaphillis, G., Asimakos, S., \& Moore, S. (2010). Financing social economy organizations. Knowledge Mobilization Paper Series. Victoria, B.C.: Canadian Social Economy Research Partnerships, University of Victoria. Retrieved http://socialeconomyhub.ca/sites/socialeconomyhub.ca/files/KM_FINANCING.pdf

Lee, A. (2015). Vague, voluntary, and void: A critique of the British Columbia community contribution company 
hybrid model. University of British Columbia Law Review, 48, 179-220.

Liao, C. (2013). The next stage of CSR for Canada: Transformational corporate governance, hybrid legal structures, and the growth of social enterprise. McGill International Journal of Sustainable Development Law and Policy, 9(1), 56-85.

Liao, C. (2014). Disruptive innovation and the global emergence of hybrid corporate legal structures. European Company Law, 11(2), 67-70.

Maxwell, J. (2013). Qualitative research design: An interactive approach (3rd ed.). Thousand Oaks, CA: SAGE Publications.

Myers, K., Conte, N., \& Nichols, R. (2013). Can social finance improve the outcomes of employment and training programs. Social Research and Demonstration Corporation. Retrieved from http://www.srdc.org/publications/Can-social-finance-improve-the-outcomes-of-employment-and-training-pr ograms-details.aspx

Pawson, D. (2013). Enhancing the market space for impact investing in Canada? Examining Nova Scotia's CEDIF program and the potential of equity-tax credits. Ottawa, ON: Centre for Community Innovation, Carleton University. Retrieved from http://iipcollaborative.org/wp-content/uploads/media/Pawson-IIPC-Draft_Formatted-031414.pdf

Phillips, S., \& Hebb, T. (2010). Financing the third sector: Introduction. Policy and Society, 29(3), 181-187. https://doi.org/10.1016/j.polsoc.2010.07.001

Reiser, D. B. (2010). Governing and Financing Blended Enterprise. Chicago-Kent Law Review, 85(2), 619-655. Retrieved from https://scholarship.kentlaw.iit.edu/cklawreview/vol85/iss2/6

Service Nova Scotia. (2016, June 15). Government Introduces New Business Designation. Retrieved from http://novascotia.ca/news/release/?id=20160615002

\section{Appendix A}

Listing of Community Contribution Companies in B.C. as of January, 2016

\begin{tabular}{|c|c|c|c|}
\hline & Company Name & $\begin{array}{l}\text { Year of Incorporation } \\
\text { or Conversion }\end{array}$ & Registered Office Location \\
\hline 1 & Accelerating Social Impact CCT Ltd. & 2013 & Vancouver \\
\hline 2 & Buy Social B.C. CCC Ltd. & 2014 & Vancouver \\
\hline 3 & Buy Social Canada CCC Ltd. & 2014 & Vancouver \\
\hline 4 & C3 Pro CCC Inc. & 2013 & Trail \\
\hline 5 & Cedar Rock Enterprises CCC Ltd. & 2013 & Vancouver \\
\hline 6 & $\begin{array}{l}\text { Cedrick's Coffee House Community } \\
\text { Contribution Company Ltd. }\end{array}$ & 2014 & Duncan \\
\hline 7 & Crowdgift Canada CCC Ltd. & 2015 & Coquitlam \\
\hline 8 & $\begin{array}{l}\text { Fair Money Community Contribution } \\
\text { Company Ltd. }\end{array}$ & 2014 & Vancouver \\
\hline 9 & $\begin{array}{l}\text { FeedingChange Foods Canada Community } \\
\text { Contribution Company Inc. }\end{array}$ & 2013 & Vancouver \\
\hline 10 & $\begin{array}{l}\text { Good Ventures Community Contribution } \\
\text { Company Ltd. }\end{array}$ & 2013 & Vancouver \\
\hline 11 & Green Zebra Urban Markets CCC Ltd. & 2015 & Coquitlam \\
\hline 12 & Grist Mill CCC Corp. & 2015 & Keremeos \\
\hline 13 & $\begin{array}{l}\text { Harmony Habitat Sustainable Building } \\
\text { Solutions CCC Inc }\end{array}$ & 2014 & Gabriola \\
\hline 14 & Institute for Marketplace Transformation & 2015 & Vancouver \\
\hline
\end{tabular}




\begin{tabular}{|c|c|c|c|}
\hline & Company Name & $\begin{array}{l}\text { Year of Incorporation } \\
\text { or Conversion }\end{array}$ & Registered Office Location \\
\hline 15 & $\begin{array}{l}\text { CCC Inc. } \\
\text { International Nursing Alliance Community } \\
\text { Contribution Company Ltd. }\end{array}$ & 2015 & Coquitlam \\
\hline 16 & Journey Home Community CCC Ltd. & 2015 & Abbotsford \\
\hline 17 & Natural Lifestyle Creations CCC Ltd. & 2014 & Errington \\
\hline 18 & Open Door Ventures CCC Ltd. & 2014 & Vancouver \\
\hline 19 & Paladin Recovery Centre CCC Inc. & 2014 & Vancouver \\
\hline 20 & PHS Community Initiatives CCC Inc. & 2013 & Vancouver \\
\hline 21 & $\begin{array}{l}\text { Road Warriors Speed Enthusiasts Xtreme } \\
\text { Custom Enthusiasts CCC Corp. }\end{array}$ & 2014 & Victoria \\
\hline 22 & $\begin{array}{l}\text { Roadway Oil Spill Response Team } \\
\text { Community Contribution Company Ltd. }\end{array}$ & 2013 & Vancouver \\
\hline 23 & $\begin{array}{l}\text { Salt Spring Events Community Contribution } \\
\text { Company Ltd. }\end{array}$ & 2015 & Victoria \\
\hline 24 & $\begin{array}{l}\text { Skin of the Salmon Community Contribution } \\
\text { Company Ltd. }\end{array}$ & 2014 & Vancouver \\
\hline 25 & Social Enterprise Institute Ltd. & 2015 & Vancouver \\
\hline 26 & $\begin{array}{l}\text { SURBL Not for Profit Community } \\
\text { Contribution Company Ltd. }\end{array}$ & 2014 & Vancouver \\
\hline 27 & $\begin{array}{l}\text { Tri-Jubilee Inter-Community Contribution } \\
\text { Company Ltd. }\end{array}$ & 2013 & Vancouver \\
\hline 28 & Urban Aboriginal task Force CCC Ltd. & 2015 & Hope \\
\hline 29 & Urban Matters CCC Ltd. & 2014 & Kamloops \\
\hline 30 & Valuenomics CCC Corp. & 2013 & Victoria \\
\hline 31 & Velofemmes Canada CCC Ltd. & 2015 & Vancouver \\
\hline 32 & $\begin{array}{l}\text { Volinspire Community Contribution } \\
\text { Company Inc. }\end{array}$ & 2015 & Kelowna \\
\hline 33 & WeShop Online CCC Ltd. & 2015 & Vancouver \\
\hline 34 & World Housing CCC Inc. & 2013 & Vancouver \\
\hline 35 & ZShips International CCC Ltd. & 2015 & Vancouver \\
\hline
\end{tabular}

\section{Copyrights}

Copyright for this article is retained by the author(s), with first publication rights granted to the journal.

This is an open-access article distributed under the terms and conditions of the Creative Commons Attribution license (http://creativecommons.org/licenses/by/4.0/). 